\title{
The effect of superficial femoral artery stenting and some atherosclerosis risk factors on changes in selected global endothelial function tests in patients with chronic lower limb ischemia. A pilot study
}

Wpływ stentowania tętnicy udowej powierzchownej i poszczególnych czynników ryzyka wystąpienia miażdżycy na zmiany wybranych parametrów globalnej funkcji śródbłonka u pacjentów z przewlekłym niedokrwieniem kończyn dolnych. Badanie pilotażowe

Jacek Budzyński', Joanna Wiśniewska², Marcin Wasielewski², Karol Suppan²

1Department of Gastroenterology, Vascular Diseases and Internal Medicine, Nicolaus Copernicus University, Ludwik Rydygier Collegium Medicum, Bydgoszcz, Poland

2The Clinical Ward of Vascular Diseases and Internal Medicine, The Dr Jan Biziel University Hospital No. 2, Bydgoszcz, Poland

Postep Kardiol Inter 2012; 8, 3 (29): 205-215

DOI: $10.5114 /$ pwki.2012.30400

\begin{abstract}
Introduction: Endothelial dysfunction is the main pathomechanism of atherosclerotic processes and their complications. Revascularization and control of atherosclerosis risk factors may improve the global endothelial function.

Aim: Assessment of the relationships between the level of selected atherosclerosis risk factors and changes in noninvasive endothelial function parameters during one year long follow-up after superficial femoral artery (SFA) stenting.

Material and methods: Seventeen male patients after SFA stenting were studied. Before the endovascular procedure, one day after it, and after 1, 3, 6, and 12 months after SFA stenting the values of global endothelial function parameters were evaluated, as follows: ankle-brachial index (ABI), flow-mediated brachial artery dilatation, distensibility coefficient, and Doppler parameters of blood flow in brachial and common carotid arteries in response to brachial ischemia and nitroglycerin sublingual application as well as intima-media complex thickness.

Results: Of the studied parameters only ABI improved significantly after SFA stenting. The changes in values of investigated endothelial function parameters were related to presence of atherosclerotic risk factors, such as age above 62 years, hypercholesterolemia, diabetes, and hypertension. Generally, global endothelial function tests were worse in patients with these conditions before the endovascular procedure, then they improved to reach the level observed in individuals without cardiovascular risk factors already after 3 to 6 months after SFA stenting.

Conclusions: The SFA stenting together with adequate pharmacotherapy may reduce the negative effect of comorbidities on the global endothelial function and vasodilatation reserve of brachial and carotid arteries.
\end{abstract}

Key words: endothelium, atherosclerosis, superficial femoral artery stenting

\section{Streszczenie}

Wstęp: Zaburzenie funkcji śródbłonka jest podstawowym mechanizmem patogenetycznym rozwoju i powikłań miażdżycy naczyń. Wiadomo, że zabieg rewaskularyzacyjny i kontrola czynników ryzyka rozwoju miażdżycy mogą poprawiać globalną funkcję śródbłonka.

Cel: Ocena związku wybranych czynników ryzyka wystąpienia miażdżycy ze zmianami wartości nieinwazyjnych wskaźników funkcji śródbłonka w ciągu rocznej obserwacji pacjentów po stentowaniu tętnicy udowej powierzchownej (TUP).

Materiał i metody: Analizie poddano wartości wskaźników zaburzenia funkcji śródbłonka u 17 mężczyzn leczonych metodą stentowania TUP z powodu chromania przestankowego. Przed zabiegiem, w dobę po stentowaniu TUP, oraz po 1, 3, 6 i 12 miesiącach od wykonania procedury wewnątrznaczyniowej zbadano: wskaźnik kostka-ramię (WKR), dylatację tętnicy ramiennej oraz wskaźnik rozszerzalności tętnicy ramiennej i szyjnej w odpowiedzi na niedokrwienie i podanie nitrogliceryny, a także parametry dopplerowskie przepływu w tętnicy ramiennej i grubość kompleksu intima-media tętnicy szyjnej wspólnej.

Corresponding author/Adres do korespondencji:

Jacek Budzyński, Clinical Ward of Vascular Diseases and Internal Medicine, The Dr Jan Biziel University Hospital No. 2, 75 Ujejskiego,

85-168 Bydgoszcz, Poland, tel./fax: +48 523655 347, e-mail: budz@cps.pl

Praca wpłynęła: 11.08.2012, przyjęta do druku: 23.08.2012. 
Wyniki: Spośród badanych parametrów jedynie WKR poprawił się istotnie po stentowaniu TUP. Wykazano natomiast znamienne różnice przebiegu zmian wartości parametrów funkcji śródbłonka w zależności od obecności czynników ryzyka wystąpienia miażdżycy, takich jak wiek > 62 lat, hipercholesterolemia, cukrzyca i nadciśnienie tętnicze. U osób z tymi schorzeniami wartości parametrów śródbłonkowych były gorsze przed zabiegiem, w kolejnych badaniach poprawiały się, osiągając po 3-6 miesiącach od zabiegu wartości obserwowane u pacjentów bez tych obciążeń.

Wnioski: Stentowanie TUP wraz z odpowiednią farmakoterapią może nie tylko poprawiać ukrwienie kończyn dolnych, lecz także niwelować negatywny wpływ chorób wspótistniejących na globalną funkcję śródbłonka i upośledzenie rezerwy wazodylatacyjnej tętnicy ramiennej i szyjnej, szczególne u osób najbardziej zagrożonych.

Słowa kluczowe: śródbłonek, miażdżyca, stentowanie tętnicy udowej powierzchownej

\section{Introduction}

Peripheral arterial disease (PAD) is often considered as a marker of diffused, multi-level or polyvascular disease. It affects approximately $30 \%$ of the population over 60 years of age and $60 \%$ of patients with coronary artery disease (CAD) [1, 2]. It is also considered as a risk factor of acute cardiovascular incidents. It doubles the risk of acute coronary syndrome and worsens the results of its treatment [1, 2]. It is known that percutaneous vascular intervention causes local injury of the vascular wall and endothelial dysfunction, which depend on the type of the stent used [3], its size and radial force [4]. However, there are reports which demonstrate a positive relationship between revascularization of the peripheral arteries and reduced frequency of acute incidents in other vascular beds, such as other peripheral arteries, coronary arteries or intracranial arteries [5-18]. The positive effect of peripheral artery stenting on all-cause and cardiovascular mortality is explained by: (a) increase of the anklebrachial index $(\mathrm{ABI})$, which is an important risk factor of death and cardiovascular events [1, 2], (b) diagnosis of atherosclerosis followed by implementation of optimal pharmacotherapy [19], (c) improvement of patients' functional status and increase of the walking distance [5, 8], (d) initiation of previously impossible cardiac rehabilitation [20], (e) improved quality of life $[5,8]$ and (f) improved global endothelial function [21-25]. Endothelial dysfunction is the endpoint for all risk factors of atherosclerosis and promotes the processes of atherogenesis through the influence on vasodilation mechanisms, stimulation of arterial thrombosis as well as migration and proliferation of vascular wall cells [26]. Endothelial function may be assessed by the measurement of concentration of substances released by these cells or by means of morphological or functional studies. The latter include the brachial artery flow-mediated dilatation (FMD) test and nitroglycerinmediated vasodilation (NMD) or acetylcholine-mediated tests. The first of the tests assesses the so-called endothelial-dependent vasodilatation and the second one the endothelial-independent vasodilatation. Other studies of similar clinical significance include pulse wave velocity measurement, peripheral arterial tonometry (PAT), assessment of the distensibility coefficient (DC), and measurement of the intima-media thickness (IMT) in the carotid artery $[18,27,28]$. It was demonstrated that reduction of FMD of the brachial artery is an indicator of global endothelial dysfunction and therefore applies to coronary, cerebral and peripheral arteries [6, 16, 23, 28-32]. The degree of FMD and PAT values reduction in response to ischemia was proportional to the number of risk factors present in the studied groups of patients and predicted the occurrence of cardiovascular incidents $[6,14,15,17,33]$ including even venous thrombosis [34]. Smoking cessation [33, 35-37], hypertension [32, 37, 38], treatment of hyperlipidemia [39-42], diabetes control [43], body mass reduction [44], improvement of physical activity [31, 45, 46] as well as peripheral revascularization involving lower extremities [16, 21-23, 26] and renal arteries [24, 25] were shown to improve the markers of endothelial function not only in the culprit lesion, but also in other vascular beds. In this context it is logical to hypothesize that control of individual risk factors of atherosclerosis may modify the course of changes of global endothelial function after percutaneous revascularization of the lower extremities.

\section{Aim}

The present study aimed to verify this hypothesis by analysis of the relation between several risk factors of atherosclerosis and changes of the markers of endothelial dysfunction in the course of 1-year observation of patients after superficial femoral artery (SFA) stenting.

\section{Material and methods}

The study included 17 men treated with SFA stenting due to chronic lower limb ischemia with presence of intermittent claudication (class IIb according to Fontaine's classification). The following inclusion criteria were formed: (a) intermittent claudication after < $200 \mathrm{~m}$ not responding to treatment (pharmacotherapy, unsupervised walking training) impeding normal daily functioning of the patient assessed objectively by walking a short distance on a treadmill; (b) confirmation of the ischemic etiology of symptoms based on the $\mathrm{ABI}(<0.9)$; (c) confirmation of atherosclerotic narrowing of the SFA by duplex scan and angiography as the main, significant cause of symptoms; (d) execution of SFA stenting; (e) patient consent to participate in the study. Patients who did not fulfill the inclusion criteria were excluded from the study. 
Medical history was obtained from each patient by means of a questionnaire. All patients underwent physical examination; inclusion and exclusion criteria were checked. Patient consent was obtained for the endovascular procedure and participation in the study. Then, after obtaining contrlateral, retrograde vascular access and the introduction of a $5 \mathrm{~F}$ sheath, angiography was performed. The SFA was then cannulated with the "crossingover" technique and the use of a hydrophilic guidewire and catheter. This was followed by exchange of the vascular sheath for the $6 \mathrm{~F}$ one. The site of stenosis was crossed inside the arterial lumen and the site of occlusion was passed using the subintimal technique. Percutaneous stenting of the SFA was performed (self-expandable nitinol stent, 6-8 $\mathrm{mm}$ of outside diameter) and followed by stent post-dilation with a $1 \mathrm{~mm}$ smaller balloon (Table 1). The procedure was finished with control angiography. Each patient underwent assessment of the following measures before the procedure (maximally one day earlier), on the first days after the procedure, and 1, 3, 6 and 12 after the procedure: clinical effect of the procedure, achievement of treatment targets in terms of risk factors reduction, $A B I$ in the supine position, intermittent claudication distance (walking test on a treadmill $3.2 \mathrm{~km} / \mathrm{h}$ with $12^{\circ}$ inclination), FMD test performed on the right upper extremity in response to $5 \mathrm{~min}$ of ischemia and administration of nitroglycerin, calculation of the DC before and after ischemia and before and after sublingual administration of $0.4 \mathrm{mg}$ of nitroglycerin (NTG) [27, 28, 47]. During these four phases of the test patients underwent assessment of Doppler flow parameters measured in the brachial artery, including peak systolic velocity (PSV), end-diastolic velocity (EDV) and their ratio, i.e. systolic to diastolic blood flow velocity (SDFV) in the brachial artery during reactive hyperemia [48], which is supposed to be a marker of arterial stiffness and microvascular disease, and percent increase of SDFV in each phase [hyperemia in response to ischemia and sublingual administration of NTG was calculated according to the equation: $100 \% \times($ SDFV after ischemia or nitroglycerin administration - SDFV before ischemia or nitroglycerin administration)/SDFV before ischemia or nitroglycerin administration]. The difference between these phases was calculated as follows: $100 \%{ }^{*}$ (increase of SDFV after NTG administration - increase of SDFV after ischemia)/increase of SDVF after ischemia. Pulsation index (PI) and resistance index (RI) were calculated automatically (USG software). Intima-media thickness and DC were assessed in the common left carotid artery [47]. Ultrasonographic examination was performed by one physician using a TOSHIBA device with a linear sensor of $7.5 \mathrm{MHz}$.

The FMD examination was performed after $10 \mathrm{~min}$ of adaptation in the supine position in a quiet room with a constant temperature. The right brachial artery was visualized in the long axis 4-5 cm above the cubital fossa and the images were recorded in parallel to the ECG tracing $[27,28]$. The diastolic diameter was defined as the inter- nal diameter of the brachial artery at the beginning of the $R$ wave and the systolic diameter as the internal diameter of the brachial artery at the beginning of the $T$ wave of the ECG. Dilatation of the brachial artery was calculated as: $100 \%{ }^{*}$ (systolic diameter-diastolic diameter)/diastolic diameter).

Measurements of the internal vascular diameter and Doppler flow were performed before the cuff inflation, $60 \mathrm{~s}$ after 5 min of pressure application on the arm with the cuff inflated up to $200 \mathrm{~mm} \mathrm{Hg}$, after $10 \mathrm{~min}$ of rest and at the $3^{\text {rd }}$ min after administration of one dose of $0.4 \mathrm{mg}$ of sublingual nitroglycerin in aerosol. Subsequently, for each of the four phases of analysis, a DC was calculated performed on the brachial artery according to the equation: $D C=2 \times$ (internal systolic diameter - internal diastolic diameter/internal diastolic diameter)/(systolic arterial pressure - diastolic arterial pressure). Values of arterial pressure obtained in $\mathrm{mm} \mathrm{Hg}$ were converted to $\mathrm{kPa}$ $(\times 0.13333)$ and presented as $10^{-3} / \mathrm{kPa}$.

The IMT was calculated $10-30 \mathrm{~mm}$ below the bifurcation of the carotid artery in 3 points free from atherosclerotic plaques on the left and right side and the results were averaged [47]. Diastolic and systolic internal diameter of the common carotid artery (assessed based on the ECG) was measured $20 \mathrm{~mm}$ below the bifurcation. Subsequently its DC was calculated according to the equation: $D C=2 \times$ (systolic diameter - diastolic diameter/diastolic diameter)/(systolic arterial pressure - diastolic arterial pressure). Values of arterial pressure obtained in $\mathrm{mm} \mathrm{Hg}$ were converted to $\mathrm{kPa}(\times 0.13333)$ and presented as $10^{-3} / \mathrm{kPa}$.

The following biochemical tests were performed: peripheral blood count, activated partial thromboplastin time (aPTT), international normalized ratio (INR), creatinine, sodium, potassium, low-density lipoprotein (LDL) cholesterol, triglycerides and glucose concentration. Pharmacotherapy was modified to include at least $75 \mathrm{mg}$ of aspirin, atorvastatin (at the dose required to reach the target level of LDL concentration < $100 \mathrm{mg} / \mathrm{dl}$ ), and angiotensin-converting enzyme inhibitor (ramipril adjusted to arterial pressure). Therapy aimed at reduction of other risk factors was also modified when necessary (according to accepted targets of treatment) [1, 2]: walking training (at least $3 \times$ per week for $60 \mathrm{~min}$ ), body weight reduction and smoking cessation. All patients were advised to take $75 \mathrm{mg}$ of clopidogrel for 28 days after SFA stenting. Patients did not require modification of therapy during subsequent visits.

\section{Statistical analysis}

The analysis was performed using a licensed 64-bit version of the Statistica 9.0 software for Windows. The analysis included the presence and intensity of the following 8 risk factors of atherosclerosis: age $>62$ years (median in the studied group), hypertension, smoking, diabetes, hypercholesterolemia (LDL cholesterol concentration > $130 \mathrm{mg} / \mathrm{dl}$ ), physical activity $<3 \times$ per week for 30 min, body mass index $>28 \mathrm{~kg} / \mathrm{m}^{2}$ (median in the studied group), waist circum- 
ference > $94 \mathrm{~cm}[1,2]$. Their influence on changes of the analyzed parameters of flow was analyzed using one- and two-way ANOVA with 6 repeats. Post-hoc analysis tests to detect the least significant difference were used.

\section{Bioethical committee}

The study was approved by the Bioethical Committee of the Nicolaus Copernicus University in Torun affiliated to the Medical College in Bydgoszcz. Each patient provided written informed consent. The protocol of the study was consistent with the Declaration of Helsinki.

Table 1. Demographic and clinical data of the studied patients $(n=17)$

Tabela 1. Dane demograficzne i kliniczne badanych pacjentów $(n=17)$

\begin{tabular}{|c|c|c|}
\hline Clinical factor & $\begin{array}{l}\text { Mean } \pm \text { standard } \\
\text { deviation or } n, \%\end{array}$ & $\begin{array}{l}\text { Minimum- } \\
\text { maximum }\end{array}$ \\
\hline Age & $60.9 \pm 6.7$ & $50-75$ \\
\hline Number of risk factors & $4.3 \pm 2.2$ & $1-8$ \\
\hline$>3$ risk factors, $n(\%)$ & $10(59 \%)$ & \\
\hline Smoking, $n(\%)$ & $10(59 \%)$ & \\
\hline Pack-years of smoking & $42.2 \pm 15.2$ & $20-80$ \\
\hline $\begin{array}{l}\text { Inadequate physical activity } \\
(<3 \times \text { per week), } n(\%)\end{array}$ & $9(52 \%)$ & \\
\hline Mean systolic pressure $[\mathrm{mm} \mathrm{Hg}]$ & $133 \pm 16$ & $105-160$ \\
\hline Mean diastolic pressure $[\mathrm{mm} \mathrm{Hg}]$ & $78 \pm 8$ & $60-100$ \\
\hline Hypertension, $n(\%)$ & $11(65 \%)$ & \\
\hline Diabetes, $n(\%)$ & $5(29 \%)$ & \\
\hline $\mathrm{LDL}>130 \mathrm{mg} / \mathrm{dl}, n(\%)$ & $11(65 \%)$ & \\
\hline $\mathrm{BMI}\left[\mathrm{kg} / \mathrm{m}^{2}\right]$ & $28.1 \pm 5.6$ & $18.2-38.8$ \\
\hline $\mathrm{BMI}>28 \mathrm{~kg} / \mathrm{m}^{2}, n(\%)$ & $9(52 \%)$ & \\
\hline Waist circumference $>94 \mathrm{~cm}, n(\%)$ & $11(65 \%)$ & \\
\hline Family history of PAD, $n(\%)$ & $8(47 \%)$ & \\
\hline Coronary artery disease, $n(\%)$ & $9(52 \%)$ & \\
\hline Cerebral artery disease, $n(\%)$ & $5(29 \%)$ & \\
\hline$A B I$ on the side of the procedure & $0.80 \pm 0.19$ & $0.5-1.13$ \\
\hline IMT on the left side & $1.2 \pm 0.3$ & $0.7-1.8$ \\
\hline Side of the procedure (left), $n(\%)$ & $8(47 \%)$ & \\
\hline TASC A/B/C, $n(\%)$ & $\begin{array}{l}3(15 \%) / \\
4(25 \%) / \\
10(60 \%)\end{array}$ & \\
\hline Stent length $[\mathrm{mm}]$ & $98 \pm 33$ & $40-150$ \\
\hline Stent diameter [mm] & $7 \pm 0.9$ & $6-8$ \\
\hline Number of implanted stents & $1.6 \pm 0.5$ & $1-2$ \\
\hline
\end{tabular}

\section{Sources of funding}

The study was funded from own resources. There is no conflict of interests.

\section{Results}

The studied group included 17 men who underwent superficial femoral artery (SFA) stenting. Demographic and clinical data of patients as well as angiographic data of the target SFA are presented in Table 1. The most frequent analyzed risk factors of atherosclerosis found at the beginning of observation included hypertension, hypercholesterolemia (LDL cholesterol > $130 \mathrm{mg} / \mathrm{dl}$ ) and increased waist circumference (>94 cm) (Table 1). Each of these factors was present in $65 \%$ of patients. More than 3 risk factors of atherosclerosis were present in 7 patients (41\%). Targets of treatment for hypertension, dyslipidemia and diabetes were reached during one-year observation. Only one patient quit smoking and attempts to normalize body mass failed. None of the studied patients experienced an acute cardiovascular event during 12 months of followup. However, at the same time 3 patients (18\%) suffered from late in-stent thrombosis caused by its fracture (treated with thrombolysis and re-stenting). Thrombosis occurred after a mean of $264 \pm 128$ days following stent implantation (after 117, 321 and 353 days).

\section{Ankle-brachial index and walking test}

SFA stenting significantly improved $A B I$ of the target limb ( $0.65 \pm 0.05$ vs. $0.92 \pm 0.03, p=0.0002)$ and insignificantly increased the relative (72 $\pm 10 \mathrm{~m}$ vs. $82 \pm 14 \mathrm{~m}, p=0.57)$ and absolute ( $124 \pm 17$ vs. $151 \pm 37 \mathrm{~m}, p=0.45$ ) distance to intermittent claudication, by an average of $14 \%$ and $22 \%$. Individual risk factors of atherosclerosis did not significantly influence the changes of $A B I$ during 12 months of follow-up (analyzed with univariate ANOVA with 6 repeats).

\section{Brachial artery flow-mediated dilatation in response to ischemia and nitroglycerin administration}

In the whole group there were no significant changes of markers of flow-mediated dilatation of the brachial artery in response to ischemia (FMD $F=1.55, p=0.19$ ) and nitroglycerin (NMD) during 12 months of observation after SFA stenting. Subgroup analysis of patients with hypercholesterolemia showed significantly lower mean FMD during the whole period of follow-up in comparison to patients with LDL cholesterol $<130 \mathrm{mg} / \mathrm{dl}$ (main effect; $F=6.6$, $p=0.033 ; 0.7 \pm 95 \% \mathrm{Cl}-3.7-5.1 \%$ vs. $9.6 \pm 95 \% \mathrm{Cl} 2.9-16.3 \%)$ (Figure 1). Moreover, patients with hypercholesterolemia, hypertension and coexistence of more than 3 risk factors had significantly lower FMD values before the procedure. These values tended to decrease in both groups in consecutive tests to reach values similar to those observed in 


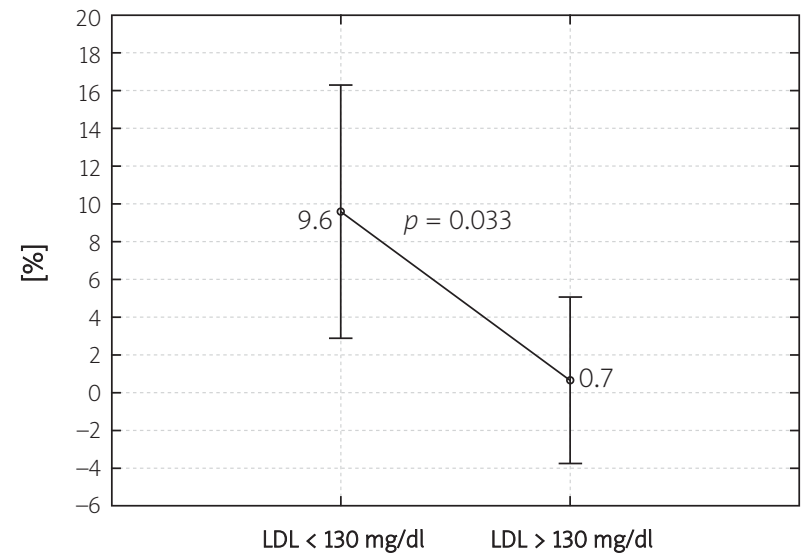

Fig. 1. Mean values of brachial artery flow mediated dilatation during 12-month observation period in relation to the LDL cholesterol plasma concentration at the study beginning. Main effect: $F=6.57$, $p=0.033$

Ryc. 1. Średnie wartości dylatacji tętnicy ramiennej w odpowiedzi na niedokrwienie w całym okresie obserwacji w zależności od wyjściowego stężenia frakcji $L D L$ cholesterolu. Efekt główny: $F=6,57$, $p=0,033$

patients without risk factors 6 months after the intervention (Figure 2). The influence of these risk factors on FMD changes did not reach statistical significance during the whole period of observation. Similar findings were noted for the association between waist circumference over $94 \mathrm{~cm}$ and NMD changes during 12 months of observation $(F=2.0, p=0.11)$. In general it can be stated that patients with various risk factors of atherosclerosis were characterized by lower flow-mediated dilatation of the brachial artery before SFA stenting in response to the stimulating factor (ischemia or NTG administration) in comparison to patients without these risk factors (Figures 1,2) and 6 patients (35\%) demonstrated even brachial artery contraction in response to ischemia. Beginning from the first day after the endovascular procedure the FMD values were positive in all patients irrespectively of the presence of risk factors, although the FMD values themselves tended to decrease. However, at the third or sixth month after the revascularization procedure the curves representing changes of FMD values in patients with and without the respective risk factor crossed and almost overlapped in the following measurements (Figure 2).

\section{Distensibility coefficient of the brachial artery}

There were no significant changes of the distensibility coefficient of the brachial artery during 12-month observation, either before the application of pressure by the cuff $(F=1.04, p=0.41)$, after its release, i.e. in response to

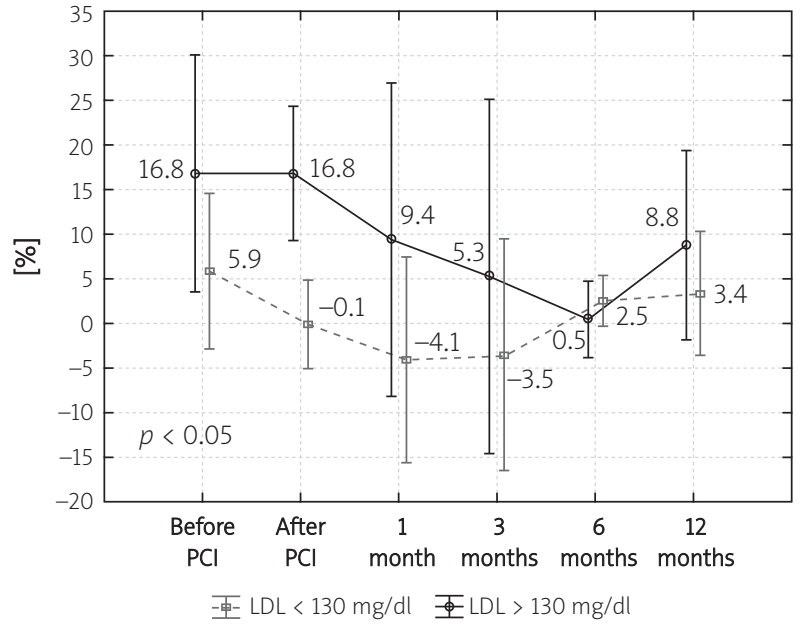

Fig. 2. Values of brachial artery flow mediated dilatation during respective visits after superficial femoral artery stenting in relation to plasma LDL cholesterol concentration at the study beginning. ANOVA: $F=1.03, p=0.41$

Ryc. 2. Wartości dylatacji tętnicy ramiennej w odpowiedzi na niedokrwienie w trakcie kolejnych wizyt po stentowaniu tętnicy udowej powierzchownej w zależności od występowania hipercholesterolemii. ANOVA: $F=1,03, p=0,41$

ischemia $(F=0.61, p=0.51)$, or after administration of NTG $(F=0.77, p=0.57)$. Statistically significant changes were also not observed for relative (\%) increase (delta) of these marker values after ischemia $(F=0.60, p=0.71)$ and after administration of NTG $(F=0.12, p=0.99)$ as well as for differences in response to both of these stimuli $(F=0.12$. $p=0.99)$ during 12 -month observation. It was only noted that patients with body mass index $(\mathrm{BMI})>28 \mathrm{~kg} / \mathrm{m}^{2}$ had significantly lower mean DC values before the exposure to ischemia and NTG $(F=7.8, p=0.023,12.8 \pm 95 \% \mathrm{Cl} 9.5$ 16.1 vs. $18.0 \pm 95 \% \mathrm{Cl}=15.3-20.7 \times 10^{-3} / \mathrm{kPa}$ ). Patients with $\mathrm{LDL}$ cholesterol concentration $>130 \mathrm{mg} / \mathrm{dl}$ had lower mean delta of the DC values for the brachial artery before and after ischemia (main effect) during 12-month observation $(F=9.81, p=0.014,-3.9 \pm 95 \% \mathrm{Cl}-8.2-0.30$ vs. $2.9 \pm 95 \% \mathrm{Cl}$ $\left.0.2-5.7 \times 10^{-3} / \mathrm{kPa}\right)$. Differences in DC values increase before the NTG administration and after exposure to ischemia were significantly lower in patients with diabetes before SFA stenting, but at 1 and 3 months after the procedure the values of this parameter in these patients were higher and subsequently equaled the values observed in patients without diabetes (Figure 3).

\section{Parameters of Doppler flow in the brachial artery}

The values of Doppler parameters of blood flow in the right brachial artery during 12 months of observation after SFA stenting did not change significantly. However, 


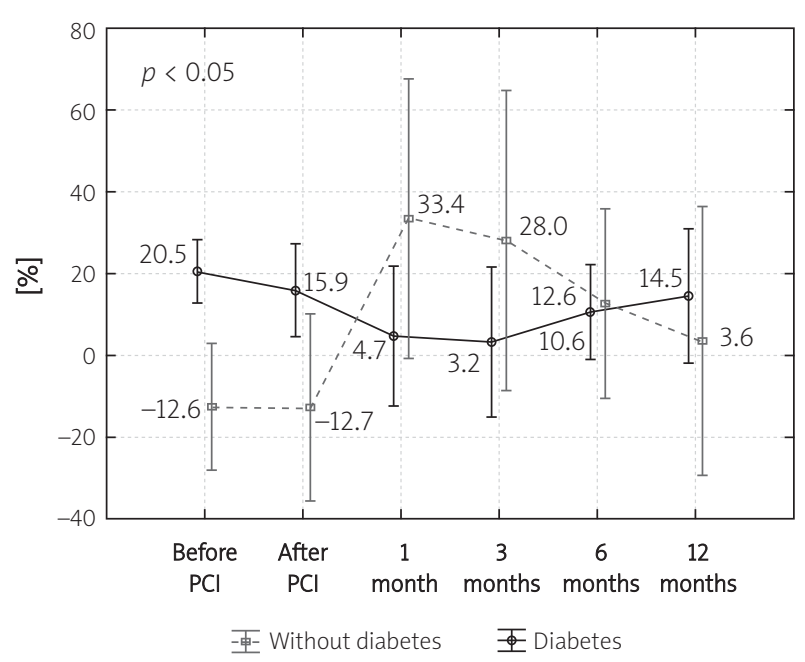

Fig. 3. Percentages differences of distensibility coefficient, DC values increase after nitroglycerin application and after brachial ischemia during 12-month follow-up after superficial femoral artery stenting in relation to diabetes presence. ANOVA: $F=5.52$, $p=0.001$

Ryc. 3. Procentowa różnica przyrostów wartości współczynnika rozszerzalności tętnicy ramiennej po podaniu nitrogliceryny i po niedokrwieniu w ciaggu 12-miesięcznej obserwacji po stentowaniu tętnicy udowej powierzchownej w zależności od występowania cukrzycy. ANOVA: $F=5,52, p=0,001$

subgroup analysis revealed a significant influence of individual risk factors on these parameters. Differences in PSV in consecutive measurements during 12-month followup both before and after the ischemia were influenced by: age $>62$ years $(F=2.77, p=0.031)$, the presence of diabetes $(F=2.12, p=0.072)$, and white blood count above the median $8.64 \mathrm{G} / \mathrm{l}(F=2.32, p=0.068)$. During observation changes of EDV before the ischemia were significantly and quite interestingly associated with the presence of diabetes $(F=5.41, p=0.0001$, Figure 4), hypertension and $\mathrm{BMI}>28 \mathrm{~kg} / \mathrm{m}^{2}$. Patients with these risk factors had higher EDV than patients without these comorbidities, but only in studies performed 1 and 3 months after SFA stenting. The EDV value in smokers assessed $1 \mathrm{~min}$ after release of 5-minute long compression of the brachial artery before the procedure was lower than in non-smokers and increased significantly 6 months after the procedure to remain at this level until the end of observation $(F=6.12$, $p=0.01$ ). Additionally, the presence of diabetes (Figure 5), increased $\mathrm{BMI}>28 \mathrm{~kg} / \mathrm{m}^{2}$ and hypercholesterolemia (LDL $>130 \mathrm{mg} / \mathrm{dl}$ ) significantly influenced changes of PSV/EDV ratio after the ischemia. The same factors significantly modified the course of delta values for PSV/EDV increase after NTG administration and ischemia. During 12 months of observation the changes of PI before the provocation with ischemia showed a significant association with



Fig. 4. Changes in end-diastolic velocity before brachial ischemia during 12-month follow-up after superficial femoral artery stenting in relation to diabetes presence. ANOVA: $F=5.46, p=0.001$

Ryc. 4. Zmiany prędkości końcoworozkurczowej $w$ tętnicy ramiennej przed jej uciskiem mankietem w zależności od występowania cukrzycy. ANOVA: $F=5,46, p=0,001$

the presence of hypertension, hypercholesterolemia $(\mathrm{LDL}>130 \mathrm{mg} / \mathrm{dl})$ and $\mathrm{BMI}>28 \mathrm{~kg} / \mathrm{m}^{2}$. Patients with these factors had higher PI. A similar course of changes was observed for the RI in patients with and without diabetes and hypercholesterolemia.

\section{Intima-media thickness in the common carotid artery}

During 12 months of observation there were no significant changes of IMT in the whole studied group of men after SFA stenting. However, IMT was modified by the presence of risk factors of atherosclerosis. During the whole period of observation the mean IMT was influenced (main effect) by age over 62 years, hypertension, diabetes and coexistence of more than 3 risk factors of atherosclerosis in one patient. Patients with these abnormalities had significantly higher mean IMT in comparison to the rest of the group. Moreover, these factors influenced the changes of IMT in consecutive measurements. Before and directly after SFA stenting patients with diabetes, BMI $>28 \mathrm{~kg} / \mathrm{m}^{2}$ and hypercholesterolemia had higher IMT than patients without these risk factors, but these values decreased with the course of time and equaled the ones observed in patients without these features after approximately 6 months of observation (Figure 6). 


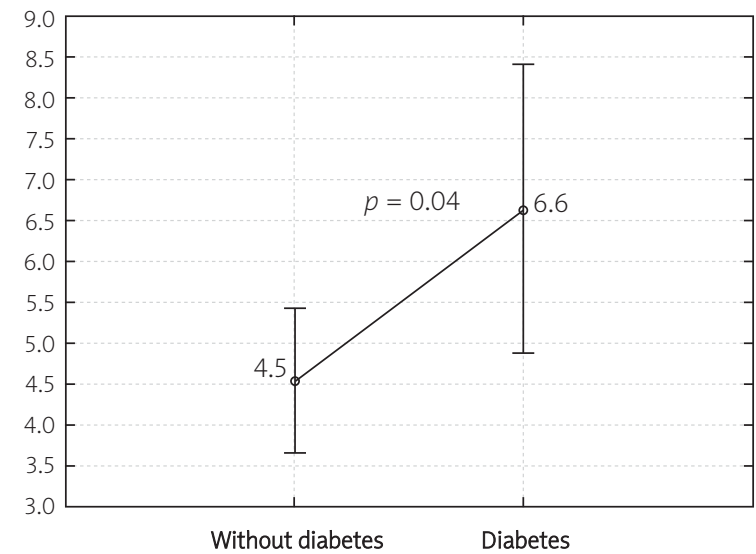

Fig. 5. Mean value of peak systolic velocity to end diastolic velocity ratio in relation to diabetes presence during 12-month follow-up after superficial femoral artery stenting. ANOVA: $F=6.06, p=0.04$ Ryc. 5. Średnia wartość PSV/EDV w 12-miesięcznej obserwacji w zależności od wspótistnienia cukrzycy. ANOVA: $F=6,06, p=0,04$

\section{Distensibility coefficient of the left carotid artery}

The time from SFA stenting as well as the presence of risk factors of atherosclerosis did not significantly influence the course of DC changes in the left carotid artery.

\section{Discussion}

In 17 patients with intermittent claudication caused by peripheral arterial disease observed for 12 months we have demonstrated a positive effect of atherosclerotic risk factors control (main effects) and effective combination of superficial femoral artery stenting (SF) and pharmacotherapy of coexisting comorbidities (interactions between time after the procedure and risk factor) on changes of values of the analyzed parameters of global endothelial function (FMD, PSV, EDV, PSV/EDV, IMT) and vascular distensibility (DC). The SFA stenting and pharmacotherapy usually did not significantly modify the course of changes of the analyzed vascular parameters in patients with adequately controlled individual risk factors of atherosclerosis (insignificant trend towards decrease of FMD values after the procedure was observed). In contrast, in patients who did not reach targets of treatment before the SFA stenting, intensification of pharmacotherapy combined with the endovascular procedure led to marked improvement of the endothelial function markers, which after 3-6 months of observation resulted in similar levels of these markers as in patients free of the given factor. These differences were most evident for IMT, FMD values and PSV/EDV ratio after the ischemia (Figures 1-6). The presented results indicate that similarly to other cardiologic

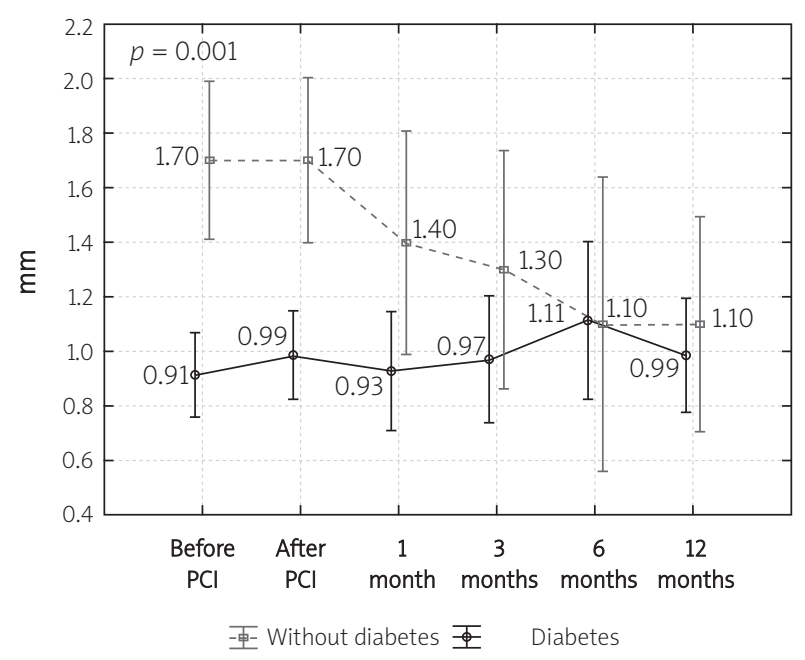

Fig. 6. Changes in intima-media complex thickness after superficial femoral artery stenting in relation to diabetes presence. $F(5,35)=4.44, p=0.003$

Ryc. 6. Zmiany grubości kompleksu intima-media w zależności od występowania cukrzycy. $F(5,35)=$ $4,44, p=0,003$

syndromes (such as acute coronary syndromes or cardiogenic shock) most benefits from the medical interventions (in this case SFA stenting and intensification of pharmacotherapy) are observed in patients at the highest risk, such as patients with uncontrolled risk factors. Our results are partially consistent with limited data from the literature that confirm the beneficial effect of peripheral artery revascularization (involving mainly lower limbs and renal arteries) on all-cause and cardiovascular mortality $[5,6,8$, $10,15,19,33$ and improvement of global endothelial function [21, 22]. In a randomized prospective study Husmann et al. [21] demonstrated in 17 patients treated with a percutaneous procedure and pharmacotherapy due to peripheral arterial disease of the lower limbs that FMD values increased after 4 weeks of observation in contrast to patients treated only with pharmacotherapy $(n=16)$, in whom these values remained unchanged. On the other hand, Unal et al. [22] found in a group of 54 patients that revascularization with the use of a femoro-popliteal PTFE prosthesis led to a significant rise of FMD values and decrease of the following markers in blood: nitric oxide, high-sensitivity C-reactive protein, interleukin- 6 and tumor necrosis factor $\alpha$ (TNF- $\alpha$ ). The authors of these studies proposed several potential mechanisms to explain the beneficial effect of peripheral revascularization on the global endothelial function: (a) secondary to increased physical activity increase of the shear stress, which is the most potent stimulus for endothelial production of nitric oxide [21], (b) reduction of oxidative stress caused by exertional ischemia before the procedure and by numerous episodes of post-ischemic reperfusion in the lower limb muscles [21], 
and (c) decreased activity of the inflammatory processes dependent on oxidative stress, cytokines and adhesion molecules released from the ischemic area [22, 49]. Other studies showed that oxidative stress causing oxidation of LDLs is a key factor for the processes of atherogenesis (oxidative hypothesis of atherosclerosis). Globally oxidized LDLs (ox-LDLs): (1) act as a chemotactic factor for inflammatory cells, (2) cause transformation of macrophages into foam cells, (3) change the endothelial response to various stimulating factors (hypertension, hypercholesterolemia, homocysteine, etc.), (4) stimulate endothelium to synthesize adhesion molecules (ICAM-1, VCAM-1, MCP-1), (5) sensitize vascular wall cells to growth factors and cytokines, (6) activate platelets, (7) decrease the secretion of tissue plasminogen activator (t-PA) and increase the secretion of its inhibitor (PAI-1), interleukin-1 and TNF- $\alpha$, (8) stimulate migration and proliferation of smooth muscle cells, and (9) counteract the vasodilative effect of nitric oxide. These mechanisms sustain the oxidative stress in the vascular wall, which despite lack of impaired antioxidative defense in the atheromatic lesion leads to progressive slow oxidation of LDLs and lipoprotein(a). This causes local creation of minimally oxidized LDL ( $m-L D L)$, and subsequently fully oxidized LDL (ox-LDL). Ox-LDLs are absorbed by monocytes and macrophages, but not via the physiological pathway through the LDL receptor (LDL absorption undergoing autoregulation), but via the so-called scavenger receptor and phagocytosis. The latter two pathways do not undergo autoregulation and lead to accumulation of cholesterol in the macrophages followed by their transformation into foam cells. Disintegration of these cells results in destabilization of the atherosclerotic plaque and thrombus formation, which are the main pathogenetic mechanisms of acute cardiovascular events.

There are no reports in the literature regarding the importance of control of atherosclerotic risk factors in the improvement of endothelial function after a percutaneous vascular procedure due to chronic lower limb ischemia with long-term follow-up. However, an association between individual risk factors and the onset of atherosclerosis, its progression and occurrence of its acute clinical manifestations was repeatedly demonstrated [2]. It was also shown that achievement of target levels of reduction of these factors permitted the progression of atherosclerotic plaque to be slowed down or stopped and the frequency of cardiovascular incidents to be decreased [1, 2]. It was also shown that smoking, diabetes, obesity and hypertension are related to impaired endothelial function and decreased vascular distensibility [36, 38-41, 44, 45, 50, 51].

In this context it may be somewhat surprising to note that except for the result of a single analysis (change in EDV values) we did not demonstrate a statistically significant influence of smoking on changes of endothelial function after SFA stenting. It may be explained by the fact that almost all patients after SFA stenting continued smoking and show that control of other risk factors had a greater influence on the improvement of endothelial function than the revascularization procedure itself. On the other hand, it is known that smoking increases the concentration of methemoglobin in blood, which has been shown to decrease the risk of in-stent restenosis and thrombosis through anti-inflammatory action, faster healing of injured vascular wall after stenting and inhibition of vascular smooth muscle cell proliferation [50]. It is also known that smokers are characterized by a more potent antiplatelet effect of clopidogrel, which depends on the induction of cytochrome P450 [52].

In several analyses we have demonstrated the beneficial effect of SFA stenting and treatment of hypercholesterolemia ( $\mathrm{LDL}>130 \mathrm{mg} / \mathrm{dl}$ ) on the improvement of global markers of endothelial function in the arteries of the upper extremities and neck (Figure 2). Spring et al. [39] noted the improvement of endothelial dysfunction in patients with peripheral arterial disease treated with atorvastatin. However, these authors did not analyze patients after SFA stenting or the relation between markers of endothelial function and LDL concentration. Other very important risk factors of endothelial dysfunction and peripheral arterial disease include age, visceral obesity, hypertension, diabetes, and physical activity [1, 2, 36, 38$41,44,45,48,50,51]$. None of the studies which demonstrated the influence of reduction of these factors on the improvement of markers of endothelial function included patients after a vascular procedure.

These pilot results, innovative even for world literature, because of the one-year observation period in patients after an endovascular procedure, may have, if confirmed, a potentially great clinical significance. We confirmed that lower limb ischemia may influence global endothelial function and on the other hand that revascularization and control of the risk factors may improve endothelial function through many mechanisms which have been demonstrated in the literature [1, 2, 21, 22]. The greatest benefits in terms of improvement of endothelial function markers after SFA stenting were observed in patients with the presence of risk factors of atherosclerosis, and therefore in the most vulnerable subjects. In these patients an endovascular procedure with best medical treatment (BMT) reduced the negative influence of risk factors on endothelial function to the level observed in patients without these risk factors (for example diabetes) as soon as 3-6 months after the procedure.

This suggests a potential possibility to obtain improvement of prognosis after vascular procedures on peripheral arteries, for example in patients with multi-vessel coronary artery disease not qualifying for coronary revascularization or in patients after interventions on coronary arteries who require intensive rehabilitation [9, 22]. These pleiotropic effects of SFA stenting and intensification 
of pharmacotherapy may change the clinical significance of this procedure in some groups of patients. In this context the procedure not only improves the quality of life [7], but also favorably changes the statistics of hard clinical endpoints [5]. Confirmation of this observation in subsequent studies could be a prerequisite to perform endovascular procedures at an earlier stage of development of peripheral arterial disease.

The study is limited mainly by the low power of the statistical analyses, caused mainly by the low number of patients in the studied group, although 17 patients were also included in one of the subgroups in the Husmann et al. study [21]. Despite this fact we were able to obtain statistical significance for some differences between the analyzed parameters, which may be a starting point for planning future studies including hard cardiological endpoints. The second limitation of the study is the lack of a control group and the fact that intensification of atherosclerotic risk factors control was performed in all patients who underwent SFA stenting, which did not permit us to analyze the influence of the percutaneous procedure itself on endothelial function. The analysis might also have been confounded by the potential difference in physical activity of patients after the procedure (walking training), which could have impacted the improvement of endothelial function. However, the walking distance on a treadmill did not increase significantly and did not differ between groups of patients with and without the given risk factor, and therefore it seems that potential differences in activity between subgroups may be omitted. Another important factor disturbing the analysis of subgroups was the uneven distribution of clinical and demographic data of patients. However, because the analysis included up to 10 risk factors it was difficult to obtain a balance of these characteristics between the subgroups.

\section{Conclusions}

Combined treatment of peripheral arterial disease of the lower limbs including peripheral femoral artery stenting together with detection and control of risk factors may not only improve the circulation of blood in the lower extremities and increase the distance to intermittent claudication, but may also reduce the negative impact of risk factors of atherosclerosis on global endothelial function and impairment of vasodilating reserve of the brachial and carotid arteries, especially in the highest-risk patients. However, further studies and longer follow-up are required to determine the influence of the endovascular procedure itself on global endothelial function and the occurrence of hard clinical end-points.

\section{References}

1. European Stroke Organisation; Authors/Task Force Members, Tendera M, Aboyans V, Bartelink ML, et al. ESC Guidelines on the diagnosis and treatment of peripheral artery diseases:
Document covering atherosclerotic disease of extracranial carotid and vertebral, mesenteric, renal, upper and lower extremity arteries: the Task Force on the Diagnosis and Treatment of Peripheral Artery Diseases of the European Society of Cardiology (ESC). Eur Heart J 2011; 32: 2851-2906.

2. Norgren L, Hiatt WR, Dormandy JA, et al. Inter-society consensus for the management of peripheral arterial disease. Int Angiol 2007; 26: 81-157.

3. Rha SW, Chen KY, Oh DJ, et al. Impact of heterogeneous overlapping drug-eluting stents on the arterial responses of rabbit iliac arteries: a comparison with overlapping bare metal stents. Korean Circ J 2012; 42: 397-405.

4. Freeman JW, Snowhill PB, Nosher JL. A link between stent radial forces and vascular wall remodeling: the discovery of an optimal stent radial force for minimal vessel restenosis. Connect Tissue Res 2010; 51: 314-326.

5. Giugliano G, Di Serafino L, Perrino C, et al. Effects of successful percutaneous lower extremity revascularization on cardiovascular outcome in patients with peripheral arterial disease. Int J Cardiol 2012.

6. Gokce N, Keaney JF Jr, Hunter LM, et al. Predictive value of noninvasively determined endothelial dysfunction for longterm cardiovascular events in patients with peripheral vascular disease. J Am Coll Cardiol 2003; 41: 1769-1775.

7. Kalbaugh CA, Taylor SM, Blackhurst DW, et al. One-year prospective quality-of-life outcomes in patients treated with angioplasty for symptomatic peripheral arterial disease. J Vasc Surg 2006; 44: 296-302.

8. Blinc A, Kozak M, Sabovic M, et al. Prevention of ischemic events in patients with peripheral arterial disease design, baseline characteristics and 2-year results an observational study. Int Angiol 2011; 30: 555-566.

9. Kitta Y, Obata JE, Nakamura T, et al. Persistent impairment of endothelial vasomotor function has a negative impact on outcome in patients with coronary artery disease. J Am Coll Cardiol 2009; 53: 323-330.

10. Corrado E, Camarda P, Coppola G, et al. Prognostic role of endothelial dysfunction and carotid intima-media thickness in patients undergoing coronary stent implantation. Int Angiol 2009; 28: 12-19.

11. Akcakoyun M, Kargin R, Tanalp AC, et al. Predictive value of noninvasively determined endothelial dysfunction for long-term cardiovascular events and restenosis in patients undergoing coronary stent implantation: a prospective study. Coron Artery Dis 2008; 19: 337-343.

12. Worthley MI, Charbonneau F, Anderson TJ. Can the measurement of impaired flow-mediated dilation predict in-stent restenosis? Nat Clin Pract Cardiovasc Med 2005; 2: 238-239.

13. Yeboah J, Folsom AR, Burke GL, et al. Predictive value of brachial flow-mediated dilation for incident cardiovascular events in a population-based study: the multi-ethnic study of atherosclerosis. Circulation 2009; 120: 502-509.

14. Santos-García D, Blanco M, Serena J, et al. Impaired brachial flowmediated dilation is a predictor of a new-onset vascular event after stroke. Cerebrovasc Dis 2011; 32: 155-162.

15. Heitzer T, Schlinzig T, Krohn K, Meinertz T, Münzel T. Endothelial dysfunction, oxidative stress, and risk of cardiovascular events in patients with coronary artery disease. Circulation 2001; 104: 2673-2678. 
16. Anderson TJ, Uehata A, Gerhard MD, et al. Close relation of endothelial function in the human coronary and peripheral circulations. J Am Coll Cardiol 1995; 26: 1235-1241.

17. Neunteufl T, Katzenschlager R, Hassan A, et al. Systemic endothelial dysfunction is related to the extent and severity of coronary artery disease. Atherosclerosis 1997; 129: 111-118.

18. Rubinshtein R, Kuvin JT, Soffler M, et al. Assessment of endothelial function by non-invasive peripheral arterial tonometry predicts late cardiovascular adverse events. Eur Heart J 2010; 31: 1142-1148.

19. Diehm C, Allenberg JR, Pittrow D, et al. Mortality and vascular morbidity in older adults with asymptomatic versus symptomatic peripheral artery disease. Circulation 2009; 120: 2053-2061.

20. Spronk S, White JV, Ryjewski C, et al. Invasive treatment of claudication is indicated for patients unable to adequately ambulate during cardiac rehabilitation. J Vasc Surg 2009; 49: 1217-1225.

21. Husmann M, Dörffler-Melly J, Kalka C, et al. Successful lower extremity angioplasty improves brachial artery flow-mediated dilation in patients with peripheral arterial disease. J Vasc Surg 2008; 48: 1211-1216.

22. Unal O, Karatepe O, Ugurlucan M, et al. Effects of lower extremity revascularization on the endothelial functions measured with noninvasive brachial artery flow-mediated dilatation. Ann Vasc Surg 2011; 25: 969-974.

23. Poredos $P$, Golob $M$, Jensterle $M$. Interrelationship between peripheral arterial occlusive disease, carotid atherosclerosis and flow mediated dilation of the brachial artery. Int Angiol 2003; 22: 83-87.

24. Jacomella V, Husmann M, Thalhammer C, et al. Impact of endovascular treatment of atherosclerotic renal artery stenosis on endothelial function and arterial blood pressure. Int Angiol 2012; 31: 70-76.

25. Koivuviita N, Tertti R, Luotolahti $M$, et al. The effect of revascularization of atherosclerotic renal artery stenosis on coronary flow reserve and peripheral endothelial function. Nephron Clin Pract 2011; 118: c241-c248.

26. Pellegrino T, Storto G, Filardi PP, et al. Relationship between brachial artery flow-mediated dilation and coronary flow reserve in patients with peripheral artery disease. J Nucl Med 2005; 46: 1997-2002.

27. Neubauer-Geryk J, Bieniaszewski L. Metody oceny funkcji śródbłonka. Wazodylatacja tętnicy ramiennej po niedokrwieniu. Choroby Serca i Naczyń 2007; 4: 190-196.

28. Corretti MC, Anderson TJ, Benjamin EJ, et al. Guidelines for the ultrasound assessment of endothelial-dependent flowmediated vasodilation of the brachial artery: a report of the International Brachial Artery Reactivity Task Force. J Am Coll Cardiol 2002; 39: 257-265.

29. Brevetti G, Silvestro A, Schiano V, Chiariello M. Endothelial dysfunction and cardiovascular risk prediction in peripheral arterial disease: additive value of flow-mediated dilation to ankle-brachial pressure index. Circulation 2003; 108: 2093-2098.

30. Huang AL, Silver AE, Shvenke E, et al. Predictive value of reactive hyperemia for cardiovascular events in patients with peripheral arterial disease undergoing vascular surgery. Arterioscler Thromb Vasc Biol 2007; 27: 2113-2119.

31. Andreozzi GM, Leone A, Laudani R, et al. Acute impairment of the endothelial function by maximal treadmill exercise in patients with intermittent claudication, and its improvement after supervised physical training. Int Angiol 2007; 26: 12-17.
32. Perticone F, Ceravolo R, Pujia A, et al. Prognostic significance of endothelial dysfunction in hypertensive patients. Circulation 2001; 104: 191-196.

33. Hamburg NM, Palmisano J, Larson MG, et al. Relation of brachial and digital measures of vascular function in the community: the Framingham heart study. Hypertension 2011; 57: 390-396.

34. Mazzoccoli G, Grilli M, Ferrandino F, et al. Arterial endothelial dysfunction and idiopathic deep venous thrombosis. J Biol Regul Homeost Agents 2011; 25: 565-573.

35. Rotolo A, Andolina G, Cospite V, et al. Endothelial dysfunction, intima-media thickness and coronary reserve in relation to risk factors and Framingham score in patients without clinical atherosclerosis. J Hypertens 2006; 24: 1581-1588.

36. Sharif MA, Bayraktutan U, Arya N, et al. Smoking impairs endothelial function in human saphenous vein in an ex vivo model. Ann Vasc Surg 2009; 23: 116-121.

37. Inoue T, Matsuoka H, Higashi Y, et al. Flow-mediated vasodilation as a diagnostic modality for vascular failure. Hypertens Res 2008; 31: $2105-2113$

38. Xu JZ, Zhang Y, Wu SN, et al. Impaired endothelial function in hypertensive patients with target organ damage. J Hum Hypertens 2009; 23: 751-757.

39. Spring S, Simon R, van der Loo B, et al. High-dose atorvastatin in peripheral arterial disease (PAD): effect on endothelial function, intima-media-thickness and local progression of PAD. An open randomized controlled pilot trial. Thromb Haemost 2008; 99 : 182-189.

40. Chen H, Ren JY, Wu B, et al. The effects after withdrawal of simvastatin on brachial artery endothelial function in patient with coronary heart disease or risk factors. Zhonghua Xin Xue Guan Bing Za Zhi 2007; 35: 531-535.

41. Leyon JJ, Jaiveer S, Connolly DL, Babu S. Statin prescription is essential in peripheral vascular disease. J VascInterv Radiol 2010; 21: 175-177.

41. Rosenbaum MA, Miyazaki K, Graham LM. Hypercholesterolemia and oxidative stress inhibit endothelial cell healing after arterial injury. J Vasc Surg 2012; 55: 489-496.

43. Bissinger A, Grycewicz T, Grabowicz W, Lubiński A. Endothelial function and left ventricular remodeling in diabetic and nondiabetic patients after acute coronary syndrome. Med Sci Monit 2011; 17: CR73-CR77.

44. Mavri A, Poredoš P, Suran D, et al. Effect of diet-induced weight loss on endothelial dysfunction: early improvement after the first week of dieting. Heart Vessels 2011; 26: 31-38.

45. Payvandi L, Dyer A, McPherson D, et al. Physical activity during daily life and brachial artery flow-mediated dilation in peripheral arterial disease. Vasc Med 2009; 14: 193-201.

46. Dod HS, Bhardwaj R, Sajja V, et al. Effect of intensive lifestyle changes on endothelial function and on inflammatory markers of atherosclerosis. Am J Cardiol 2010; 105: 362-367.

47. Stróżecki P, Serafin Z, Kurowski R, et al. Carotid arteries remodeling in chronic kidney disease. Acta Angiologica 2006; 13: 106-116.

48. Järhult SJ, Hansen T, Ahlström H, et al. Brachial artery hyperaemic blood flow velocity in relation to established indices of vascular function and global atherosclerosis: the Prospective Investigation of the Vasculature in Uppsala Seniors study. Clin Physiol Funct Imaging 2012; 32: 227-233.

49. Tondi P, Santoliquido A, Di Giorgio A, et al. Endothelial dysfunction as assessed by flow-mediated dilation in patients with cardiac syndrome X: role of inflammation. Eur Rev Med Pharmacol Sci 2011; 15: 1074-1077. 
50. Schillinger $M$, Exner $M$, Mlekusch $W$, et al. Effect of smoking on restenosis during the 1st year after lower-limb endovascular interventions. Radiology 2004; 231: 831-838.

51. Smolock CJ, Anaya-Ayala JE, Bismuth J, et al. Impact of metabolic syndrome on the outcomes of superficial femoral artery interventions. J Vasc Surg 2012; 55: 985-993.e1.

52. Gurbel PA, Nolin TD, Tantry US. Clopidogrel efficacy and cigarette smoking status. JAMA 2012; 307: 2495-2496. 